\title{
ANALISIS KEMAMPUAN LITERASI MATEMATIKA MAHASISWA DALAM PENYELESAIAN SOAL HIGHER ORDER THINKING SKILLS (HOTS) DITINJAU PADA LEVEL 5 PISA
}

\author{
Yustina Dwi Astuti ${ }^{1}$, Zacharias Angelius Krisna Wara Sabon ${ }^{2}$ \\ ${ }^{1,2}$ Universitas Sanata Dharma \\ Ystna29@gmail.com
}

\begin{abstract}
Abstrak: Tujuan dari penelitian ini yaitu mendeskripsikan kemampuan literasi matematikamahasiswa dalam penyelesaian soal Higher Order Thinking Skills (HOTS) ditinjau pada Level 5 PISA. Jenis penelitian yang digunakan adalah deskripsi kualitatif. Subjek dalam penelitian ini adalah mahasiswa semester 5, sebanyak 16 mahasiswa. Instrumen penelitian yang digunakan adalah soal tes dengan indikator HOTS pada level 5. Jenis penelitian ini adalah deskriptif kualitatif dimana hasil dari penelitian ini mendeskripsikan secara rinci untuk menjawab tujuan dari penelitian. Berdasarkan tujuan penelitian yang telah dirumuskan, diperoleh hasil dari penelitian ini yaitu: melalui hasil deskripsi proses berpikir subjek dan hasil analisis ketercapaian indikator HOTS, soal dengan tingkat kesulitan tinggi yang berada pada level 5 belum dapat diselesaikan oleh ke 16 subjek penelitian. Dari 16 subjek tersebut, peneliti melakukan reduksi data berdasarkan proses pengerjaan yang dilakukan sehingga menghasilkan empat kelompok jawaban yang berbeda. Pada soal HOTS level 5 terdapat tujuh mahasiswa yang memiliki kemampuan matematika PISA yakni S2, S5, S7,S9, S13, S11, dan S16 yang memenuhi keempat indikator.
\end{abstract}

Kata Kunci: HOTS, PISA, Kemampuan Literasi

\begin{abstract}
The purpose of this study is to describe the ability of mathematical literacy in solving Higher Order Thinking Skills (HOTS) questions reviewed at Level 5 PISA for Undergraduate Mathematics Education Students. The type of research used is a qualitative description. The subjects in this study were 16 students in the 5th semester of the mathematics education study program. The research instrument used is a test item with HOTS indicator at level 5. This research method is descriptive qualitative where the results of this study describe in detail to answer the objectives of the study. Based on the research objectives that have been formulated, the results obtained from this study are: Based on the results of the description of the subject's thinking process and the results of the analysis of the HOTS indicator achievement, the questions with a high level of difficulty at level 5 cannot be solved by the 16 research subjects. Of the 16 subjects, the researcher reduced the data based on the work done so as to produce four different answer groups. In level 5 HOTS questions, there are six students who have PISA math skills, namely S2, S5, S9, S13, S11, S16 fulfilling the four indicators.
\end{abstract}

Keywords: HOTS, PISA, Literacy Skills

Cara Sitasi: Astuti D. Y., Sabon W.K.A.Z. (2020). Analisis Kemampuan Literasi Matematika Mahasiswa dalam Penyelesaian Soal Higher Order Thinking Skills (HOTS) ditinjau pada Level 5 PISA. Asimtot: Jurnal Kependidikan Matematika, “2”("2”), “91 - 101" 


\section{ASIMTOT: JURNAL KEPENDIDIKAN MATEMATIKA}

Volume 2 Nomor 2, Juni - November 2020, halaman 91 - 101

Tersedia Daring pada https://journal.unwira.ac.id/index.php/ASIMTOT

Dunia Pendidikan, secara global saat ini terdapat dua asesmen utama berskala internasional yang menilai kemampuan matematika dan sain siswa, yaitu TIMSS (Trend in International Mathematics and Science Study) dan PISA (Program for International Student Assessment). PISA dilaksanakan secara regular sekali dalam tiga tahun sejak tahun 2000 untuk mengetahui literasi siswa usia 15 tahun. Fokus dari PISA adalah literasi yang menekankan pada keterampilan dan kompetensi siswa yang diperoleh dari sekolah dan dapat digunakan dalam kehidupan sehari-hari dan dalam berbagai situasi (Stacey, 2011)

Program for International Student Assessment (PISA) merupakan studi internasional yang diselenggarakan negaranegara yang tergabung dalam OECD (Organization for Economic Co-operation and Development). PISA dilakukan secara berkala yaitu tiga tahun sekali. Studi ini meneliti dalam kemampuan membaca (reading literacy), matematika (mathematical literacy), sains (scientific literacy), finansial (financial literacy) dan pemecahan masalah (problem solving) (OECD, 2013).

Untuk PISA 2012, literasi atau melek matematika didefinisikan sebagai kemampuan seseorang individu merumuskan, menggunakan, dan menafsirkan matematika dalam berbagai konteks. Termasuk di dalamnya bernalar secara matematis dan menggunakan konsep, prosedur, fakta, dan alat matematika dalam menjelaskan serta memprediksi fenomena. Dengan demikian literasi matematika membantu seseorang untuk mengenal peran matematika dalam dunia dan membuat pertimbangan maupun keputusan yang dibutuhkan sebagai warga negara (OECD, 2010).

Literasi matematika menjadi salah satu aspek yang diukur dalam studi The Programme for Internasional Student Assessment (PISA). Penilaian prestasi matematika pada tingkat internasional merupakan indikator yang penting untuk dirujuk dalam melakukan evaluasi pendidikan suatu negara salah satunya dapat mengevaluasi keberhasilan kurikulum yang telah berjalan di negara masing-masing. Selain kurikulum, kompetensi guru yang mentransfer ilmu pengetahuan kepada siswa juga sangat menentukan, karena kompetensi guru berdampak langsung dalam proses belajar mengajar di dalam kelas.

Mahasiswa fakultas keguruan dan ilmu pendidikan program studi pendidikan matematika merupakan mahasiswa yang nantinya akan menjadi seorang guru matematika di sekolah baik menengah pertama maupun atas. Sebagai calon guru, sebelum mampu menentukan strategi dan metode pengajaran yang akan dilakukan dalam kelas kepada siswanya, mahasiswa harus memiliki kompetensi dan kemampuan literasi matematika yang baik dengan berpikir tingkat tinggi agar mampu menyelesaikan dan memecahkan soal yang 


\section{ASIMTOT: JURNAL KEPENDIDIKAN MATEMATIKA}

Volume 2 Nomor 2, Juni - November 2020, halaman 91 - 101

Tersedia Daring pada https://journal.unwira.ac.id/index.php/ASIMTOT

sulit. Mahasiswa yang memiliki kemampuan literasi matematika yang baik dengan berpikir tingkat tinggi, nantinya akan mentransfer kemampuan tersebut kepada peserta didiknya.

Hal ini dibuktikan oleh Stacey pada tahun 2014 yang menunjukkan bahwa negara-negara yang menempati peringkat tinggi di PISA (Prasetyani dan Suparman, 2018). Karena guru merupakan ujung tombak keberhasilan dunia pendidikan untuk mencapai tujuan pembelajaran khususnya kepada peserta didik di dalam kelas yang diolahnya. Untuk menumbuhkan dan meningkatkan kemampuan literasi matematika dengan berpikir tingkat tinggi pada mahasiswa, sebaiknya menjadi pembiasaan untuk mengerjakan soal tingkat tinggi, seperti soal matematika model PISA yang merupakan bentuk soal yang tidak rutin sehingga mahasiswa sudah dilatih untuk menyelesaikan soal yang berbentuk penyelesaian masalah.

Presentase skor kemampuan literasi matematika siswa Indonesia pada PISA 2009 dalam menjawab soal level 5 sangat kecil jika dibandingkan dengan negara lain (Stacey, 2011). Wheeler dan Haertel mengatakan bahwa kemampuan berpikir tingkat tinggi dapat dikembangkan melalui kegiatan pemecahan masalah yang mengeksplorasi kemampuan berargumen, membandingkan, mengevaluasi, mengambil keputusan dan menarik kesimpulan (forster, 2004)
Sejalan dengan hal tersebut, analisis hasil PISA 2003-2009 menunjukkan bahwa sebagian besar siswa Indonesia tidak mampu menyelesaikan permasalahan matematika level tinggi (Widjaja, 2011). Hal ini menjadi salah satu dasar pemikiran pengembangan Kurikulum 2013. Tujuan dari Kurikulum 2013 salah satunya adalah agar siswa memperoleh pembelajaran yang sesuai dengan soal yang diujikan di tingkat internasional (Kemdikbud, 2013). Maka dari itu, pembelajaran matematika siswa disajikan dengan masalah-masalah kontekstual yang merujuk pada soal model PISA.

Berikut adalah level 5 dalam PISA dengan aktivitas yang siswa lakukan.

\begin{tabular}{|c|c|}
\hline Level & Aktivitas Yang Dilakukan Siswa \\
\hline $\begin{array}{c}\text { Level } \\
5\end{array}$ & 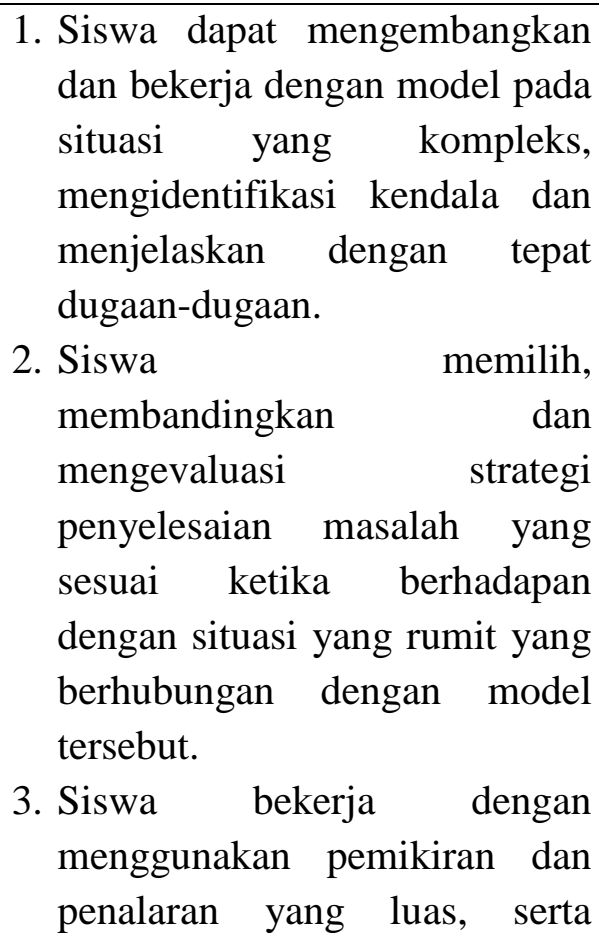 \\
\hline
\end{tabular}




\section{ASIMTOT: JURNAL KEPENDIDIKAN MATEMATIKA}

Volume 2 Nomor 2, Juni - November 2020, halaman 91 - 101

Tersedia Daring pada https://journal.unwira.ac.id/index.php/ASIMTOT

\begin{tabular}{|l|l|}
\hline secara tepat menghubungkan \\
pengetahuan dan keterampilan \\
matematikanya dengan situasi \\
yang dihadapi. \\
4. Siswa dapat melakukan refleksi \\
dari apa yang mereka kerjakan \\
dan mengkomunikasikan \\
interprestasi dan penalarannya. \\
\hline
\end{tabular}

Salah satu upaya untuk memaksimalkan aktivitas-aktivitas siswa sesuai dengan kriteria soal PISA level 5 adalah dengan membiasakan siswa dengan soal tersebut. Agar siswa terbiasa dengan soal model PISA level 5, maka dapat dilakukan dengan pemberian soal tersebut sedini mungkin atau pada awal siswa menginjak jenjang sekolah menengah (Barczi, 2008).

Banyak penelitian yang memaparkan dalam mengembangkan soal model PISA di Sekolah Menengah Pertama dengan berbagai fokus seperti Edo (2012) mengembangkan soal model PISA yang mengukurkemampuan pemodelan siswa, kemudian Lutfianto (2013) mengembangkan soal matematika model PISA konteks pribadi. Serta Mangelep (2013) telah mengembangkan soal model PISA pada kompetensi proses koneksi dan refleksi. Hingga saat ini belum ada yang mengembangkan soal model PISA dengan framework 2012 untuk diberikan pada program pengayaan, terlebih lagi diterapkan pada Kurikulum 2013.
Dari uraian di atas, peneliti tertarik melakukan penelitian analasis kemampuan literasi matematika pada mahasiswa S1 Pendidikan matematika model PISA level 5. Adapun tujuan dari penelitian ini adalah untuk mengetahui sejauh mana kemampuan mahasiswa saat mengerjakan soal yang dikembangkan. Hasil dari penelitian ini diharapkan dapat memberikan manfaat untuk menambah pemahaman mahasiswa terkait soal model PISA.

\section{Metode Penelitian}

Penelitian ini merupakan penelitian kualitatif. Penelitian ini bertujuan mendeskripsikan kemampuan Kemampuan penyelesaian Soal Higher Order Thinking Skills (HOTS) dengan Level 5 PISA. Penelitian ini dilakukan pada semester genap tahun ajaran 2019/2020 di Universitas Sanata Dharma, pada bulan Maret 2020. Subjek pada penelitian ini adalah mahasiswa S1 Pendidikan Matematika dengan jumlah sampel 16 mahasiswa. Instrumen yang digunakan dalam penelitian ini berupa soal level 5 PISA, yang akan mengukur kemampuan penyelesaian soal dari mahasiswa. Teknik pengumpulan data melalui pemberian tes, dengan rincian indikator PISA level 5 yang digunakan pada penelitian ini sebagai berikut, yaitu:

1. Siswa mampu memilih strategi penyelesaian masalah yang sesuai ketika berhadapan dengan situasi yang 


\section{ASIMTOT: JURNAL KEPENDIDIKAN MATEMATIKA}

Volume 2 Nomor 2, Juni - November 2020, halaman 91 - 101

Tersedia Daring pada https://journal.unwira.ac.id/index.php/ASIMTOT

rumit yang berhubungan dengan model tersebut dengan menentukan variabelvariabel yang sesuai dari masalah yang ada dengan menentukan variabel selisih waktu keberangkatan antara Paman dan Ayah dan membuat ilustrasi penyelesaian masalah yang ada

2. Siswa bekerja dengan menggunakan pemikiran dan penalaran yang luas dengan menggunakan pemahaman yang dimiliki sebelumnya dengan menentukan waktu menggunakan perbandingan Jarak dan kecepatan, serta secara tepat menghubungkan pengetahuan dan keterampilan matematikanya dengan situasi yang dihadapi. Siswa juga dapat melakukan perhitungan dengan data yang telah diperoleh dari penyelesaian sebelumnya yaitu waktu yang digunakan untuk menentukan paman dan ayah akan berpapasan. Selanjutnya dengan menggunakan konsep substitusi.

3. Siswa bekerja dengan menggunakan pemikiran dan penalaran yang luas dengan menggunakan pemahaman yang dimiliki sebelumnya dengan menentukan waktu menggunakan perbandingan Jarak dan kecepatan, serta secara tepat menghubungkan pengetahuan dan keterampilan matematikanya dengan situasi yang dihadapi. Siswa juga dapat melakukan perhitungan dengan data yang telah diperoleh dari penyelesaian sebelumnya yaitu waktu yang digunakan untuk menentukan paman dan ayah akan berpapasan. Selanjutnya dengan menggunakan konsep substitusi

4. Siswa mampu mengecek ulang dan menelaah kembali hasil pekerjaannya yaitu dengan menganalisis dan mengevaluasi apakah prosedur yang diterapkan dan hasil yang diperoleh benar atau apakah prosedur dapat dibuat generalisasinya dan kemudian membuat kesimpulan tentang jarak dan waktu Paman dan Ayah akan berpapasan

Berdasarkan indikator tersebut, maka soal tes dalam penelitian ini adalah:

\section{Permasalahan Level 5}

Diketahui jarak dua buah kota A dan kota B adalah $240 \mathrm{~km}$. Paman mengendarai mobil dari kota A ke kota B dengan kecepatan 40 $\mathrm{km} / \mathrm{jam}$ dan berangkat pada pukul 14.40. Pada waktu 1 jam setelahnya Ayah berangkat dari kota B ke kota A dengan kecepatan $60 \mathrm{~km} / \mathrm{jam}$. Paman dan Ayah melalui jalur yang sama. Tentukan kapan dan dimana Paman dan Ayah akan berpapasan?

Teknik analisis data yang digunakan adalah analisi data kualitatif meliputi (1) reduksi data adalah proses pemilihan halhal pokok, penyederhanaan, dan memfokuskan pada hal-hal yang sesuai dengan tujuan penelitian. (2) penyajian data berupa informasi dalam bentuk teks naratif yang disusun, diringkas, dan diatur agar 


\section{ASIMTOT: JURNAL KEPENDIDIKAN MATEMATIKA}

Volume 2 Nomor 2, Juni - November 2020, halaman 91 - 101

Tersedia Daring pada https://journal.unwira.ac.id/index.php/ASIMTOT

mudah dipahami dan merencanakan kerja penelitian selanjutnya. (3) penarikan kesimpulan adalah tahap analisis data yang telah disajikan dalam bentuk deskripsi (Sugiyono, 2016).

\section{Hasil Penelitian dan Pembahasan}

\section{Hasil}

Penelitian ini dilakukan pada 16 mahasiswa SI pendidikan matematika dengan memberikan soal Higer Order Thinking Skills (HOTS) dengan level 5 PISA sesuai dengan indikator yang telah dibuat.Berdasarkan analisis data yang dilakukan diperoleh tiga kelompok jawaban: (1) Terdapat 7 mahasiswa yakni S2, S5,S7, S9, S13, S11, S16 memenuhi keempat indikator. Subjek pada kelompok ini dapat menggunakan informasi yang ada pada permasalahan kemudian memodelkan secara matematis dan membuat rencana penyelesaian untuk menjawab permasalahan. (2) Terdapat 7 mahasiswa yakni: S1, S3, S4, S6, S8, S10, dan S12 hanya memenuhi indikator pertama. Subjek pada kelompok ini hanya dapat mengidentifikasi kendala dan menjelaskan dengan tepat dugaan-dugaan dengan cara menuliskan apa yang diketahui dalam soal, namun dalam menentukan strategi penyelesain masih kurang tepat. Serta (3) Terdapat dua mahasiswa yakni S14 dan S15 yang belum memenuhi empat indikator hal ini disebabkan kekeliruan dalam menginterpretasikan soal-soal cerita, serta kurang memahami apa yang akan dilakukan untuk menyelesaikan permasalahan terkait.

\section{Pembahasan}

Proses analisis terhadap jawaban mahasiswa dari 16 subjek tersebut, peneliti melakukan reduksi data berdasarkan proses pengerjaan yang dilakukan sehingga menghasilkan tiga kelompok jawaban, kemudian berdasarkan hasil deskripsi proses berpikir pada. kelompok 1 terdapat 7 mahasiswa yakni S2, S5, S7 S9, S13, S11, dan S16 memenuhi ke empat indikator. Berikut proses deskripsi yang dilakukan peneliti:

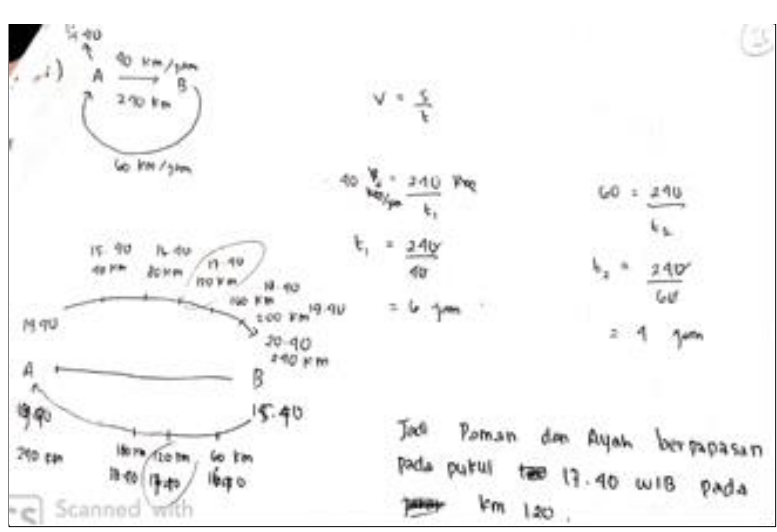

Gambar 1. Hasil Pekerjaan Mahasiswa 


\section{ASIMTOT: JURNAL KEPENDIDIKAN MATEMATIKA}

Volume 2 Nomor 2, Juni - November 2020, halaman 91 - 101

Tersedia Daring pada https://journal.unwira.ac.id/index.php/ASIMTOT

Tabel 1. Deskripsi Pekerjaan Mahasiswa kelompok 1.

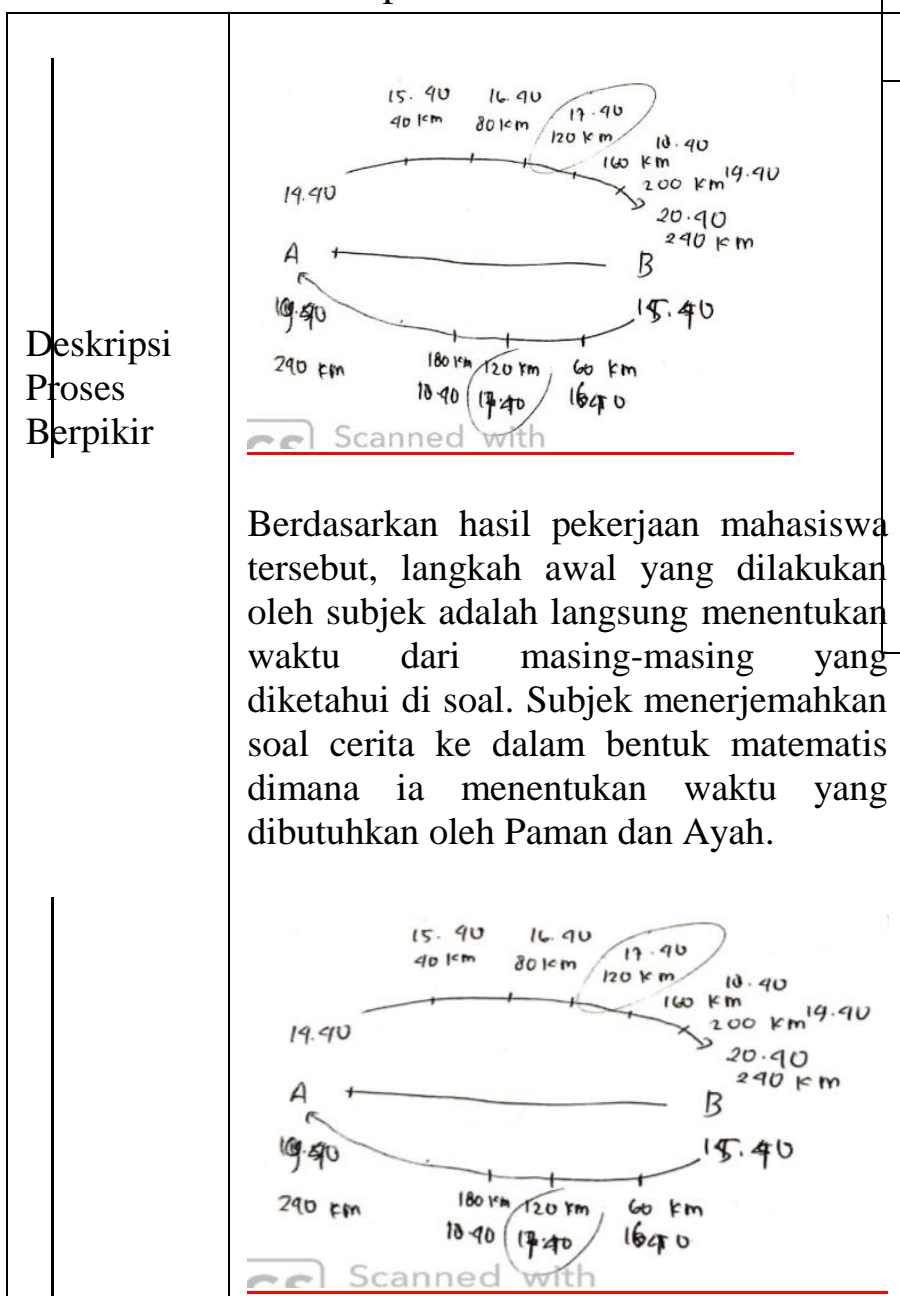

Berikutnya subjek membuat ilustrasi model matematisnya dengan membuat ilustrasi menentukan jarak Kota A dan Kota B yang ditempuh oleh Paman dan Ayah dan memperkirakan perbandingan jarak dan waktunya sekaligus.

$$
\begin{aligned}
& \text { Jadi Paman dan Ayah berpapasan } \\
& \text { pada pukul } 17.40 \text { w I B pada } \\
& 120 .
\end{aligned}
$$

Analisis Ketercapain Indikatot HOTS
Berdasarkan ilustrasi yang ada mahasiswa sudah bisa menentukan waktu dan jarak saat paman dan ayah akan berpapasan.

Berdasarkan hasil proses berpikir subjek di atas, dengan mengaitkan indikator HOTS menurut PISA pada soal. Maka, subjek yang berada pada kelompok jawaban sudah memenuhi seluruh indikator dalam soal, yakni subjek dapat menggunakan informasi berdasarkan permasalahan yang diberikan. Subjek yang berada pada kelompok ini sudah dapat menentukan informasi yang ada dengan menggunakan ilustrasi, dan sudah dapat menentukan startegi yang tepat dalam menyelesaikan soal.

Berdasarkan hasil deskripsi proses berpikir pada kelompok 2 terdapat 7 mahasiswa yakni S1, S3, S4, S6, S8, S10, dan S12 atau sebesar $43,75 \%$ hanya memenuhi indikator pertama. Berikut proses deskripsi yang dilakukan peneliti:

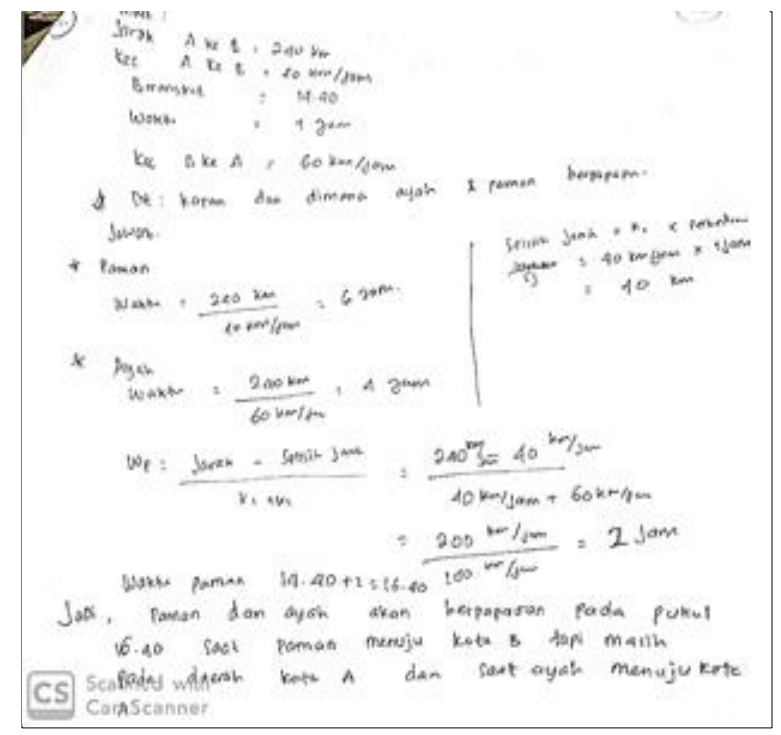

Gambar 2. Hasil Pekerjaan Mahasiswa

Vol 2. No 2, Juni - November 2020 


\section{ASIMTOT: JURNAL KEPENDIDIKAN MATEMATIKA}

Volume 2 Nomor 2, Juni - November 2020, halaman 91 - 101

Tersedia Daring pada https://journal.unwira.ac.id/index.php/ASIMTOT

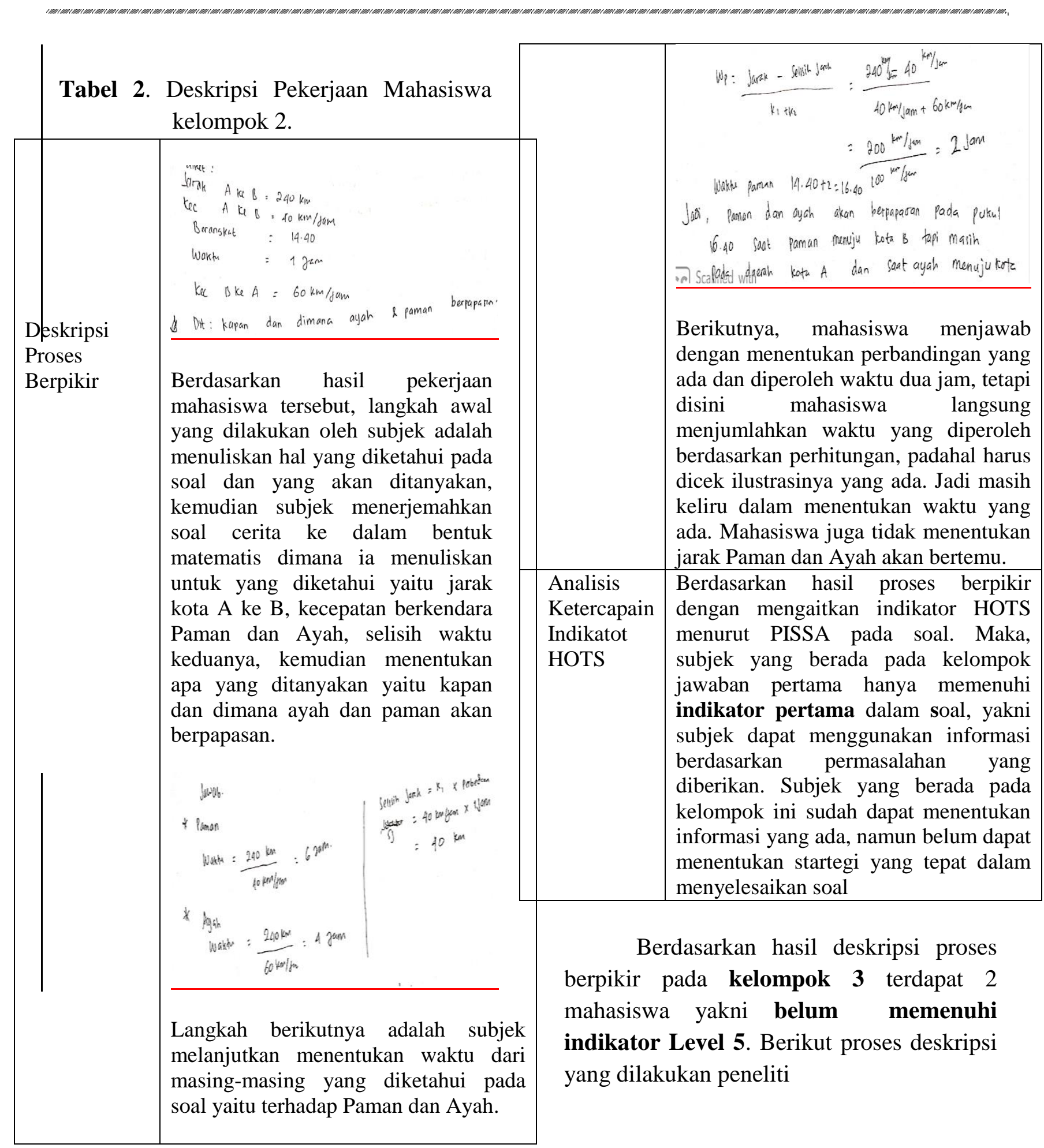


ASIMTOT: JURNAL KEPENDIDIKAN MATEMATIKA

Volume 2 Nomor 2, Juni - November 2020, halaman 91 - 101

Tersedia Daring pada https://journal.unwira.ac.id/index.php/ASIMTOT

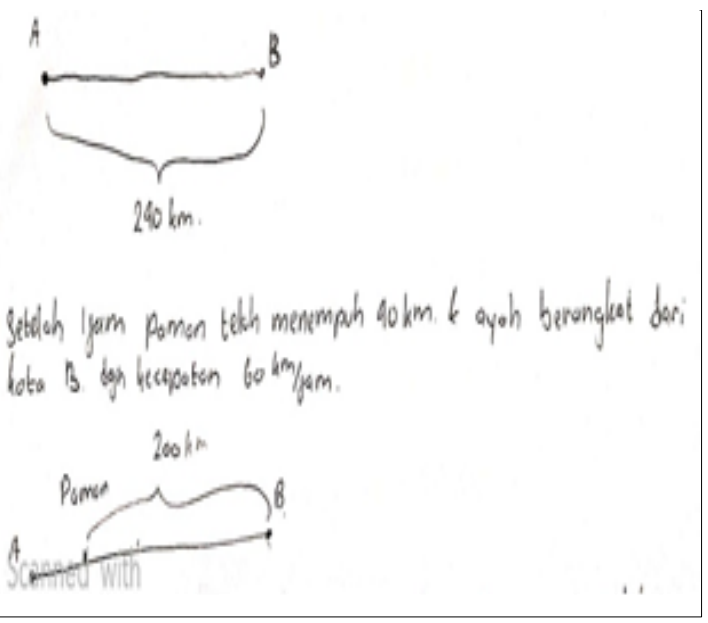

Gambar 3. Hasil Pekerjaan Mahasiswa

Tabel 3. Deskripsi Pekerjaan Mahasiswa kelompok 3.

\begin{tabular}{|c|c|}
\hline \multirow{2}{*}{$\begin{array}{l}\text { De kkripsi } \\
\text { Proses } \\
\text { Berpikir }\end{array}$} & 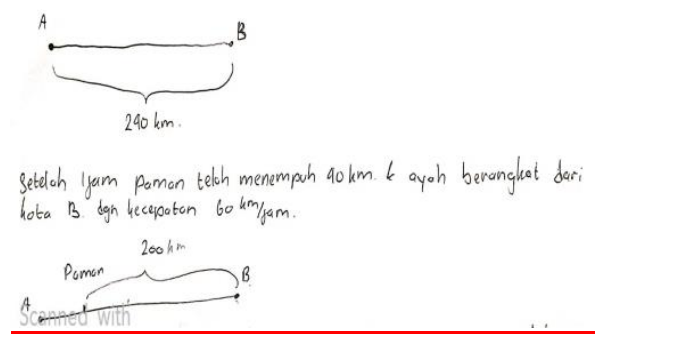 \\
\hline & $\begin{array}{l}\text { Berdasarkan jawaban yang ada } \\
\text { subjek hanya membuat ilustrasi } \\
\text { yang ada dengan menentukan jarak } \\
\text { dari kota A ke B itu sejauh } 240 \mathrm{~km} \text {, } \\
\text { selanjutnya mahasiswa tidak } \\
\text { menentukan penyelesaian lanjutan } \\
\text { untuk menyelesaikan strategi yang } \\
\text { ada. }\end{array}$ \\
\hline $\begin{array}{l}\text { Analisis } \\
\text { Ketercapain } \\
\text { Indikatot } \\
\text { HOTS }\end{array}$ & $\begin{array}{l}\text { Berdasarkan hasil proses berpikir } \\
\text { subjek di atas, dengan mengaitkan } \\
\text { indikator HOTS menurut PISSA pada } \\
\text { soal. Maka, subjek yang berada pada } \\
\text { kelompok jawaban pertama tidak } \\
\text { memenuhi indikator pertama dalam } \\
\text { soal, yakni subjek belum dapat }\end{array}$ \\
\hline
\end{tabular}

\begin{tabular}{|l|l|}
\hline menggunakan informasi berdasarkan \\
permasalahan yang diberikan. Subjek \\
yang berada pada kelompok ini belum \\
dapat menentukan informasi yang ada, \\
dan juga belum dapat menentukan \\
startegi yang tepat dalam \\
menyelesaikan soal.
\end{tabular}

Berdasarkan kelompok 1, sebanyak 7 orang mahasiswa atau sebesar $43,75 \%$ mahasiswa mencapai empat indikator yakni mahasiswa mampu menjawab soal yang mengukur kemampuan matematika level 5 dengan baik. Mahasiswa memenuhi keempatindikator HOTS menurut PISSA dapat mengembangkan dan bekerja dengan model pada situasi yang kompleks, mengidentifikasi kendala dan menjelaskan dengan tepat dugaan-dugaan. Mahasiswa telah mampu bekerja dengan menggunakan pemikiran dan penalaran yang luas, serta secara tepat menghubungkan pengetahuan dan keterampilan matematikanya dengan situasi yang dihadapi. Mahasiswa sudah mampu melakukan refleksi dari apa yang dikerjakan dan mengkomunikasikan interprestasi dan penalarannya karena maksudnya yang diberikan sudah sesuai dan benar.

Berdasarkan kelompok 2, sebanyak 7 orang mahasiswa atau sebesar $43,75 \%$ mahasiswa hanya mencapai indikator pencapaian soal yakni memodelkan masalah kontekstual ke dalam bentuk kalimat matematika. Mahasiswa hanya dapat mencapai indikator pertama pada level 5 yaitu menentukan apa yang diketahui pada 


\section{ASIMTOT: JURNAL KEPENDIDIKAN MATEMATIKA}

Volume 2 Nomor 2, Juni - November 2020, halaman 91 - 101

Tersedia Daring pada https://journal.unwira.ac.id/index.php/ASIMTOT

soal, karena di tahap selanjutnya mahasiswa tidak tau untuk menentukan langkah selanjutnya, atau mahasiswa salah dalam menentukan strategi dalam variabel yang ingin dicari. Mahasiswa belum dapat mengembangkan dan bekerja dengan model pada situasi yang kompleks, mengidentifikasi kendala dan menjelaskan dengan tepat dugaan-dugaan. Mahasiswa belum mampu bekerja dengan menggunakan pemikiran dan penalaran yang luas, serta secara tepat menghubungkan pengetahuan dan keterampilan matematikanya dengan situasi yang dihadapi. Mahasiswa juga kurang mampu melakukan refleksi dari apa yang dikerjakan dan mengkomunikasikan interprestasi dan penalarannya karena maksudnya yang diberikan tidak sesuai dan benar.

Berdasarkan kelompok 3, sebanyak 2 orang mahasiswa atau sebesar $12,5 \%$ mahasiswa belum memenuhi indikator HOTS menurut PISSA pada soal. Maka, subjek yang berada pada kelompok jawaban pertama tidak memenuhi indikator pertama dalam soal, yakni subjek belum dapat menggunakan informasi berdasarkan permasalahan yang diberikan. Subjek yang berada pada kelompok ini belum dapat menentukan informasi yang ada, dan juga belum dapat menentukan startegi yang tepat dalam menyelesaikan soal matematika diperoleh: HOTS menurut PISSA pada soal. Maka, subjek yang berada pada kelompok jawaban pertama tidak memenuhi indikator pertama dalam soal, yakni subjek belum Asimtot: Jurnal Kependidikan Matematika dapat menggunakan informasi berdasarkan permasalahan yang diberikan. Subjek yang berada pada kelompok ini belum dapat menentukan informasi yang ada, dan juga belum dapat menentukan startegi yang tepat dalam menyelesaikan soal matematika diperoleh: Pada soal HOTS level 5 terdapat tujuh mahasiswa yang memiliki kemampuan matematika PISA yakni S2, S5, S7, S9, S13, S11, dan S16 memenuhi keempat indikator. Kemampuan level 5 ini diukur dengan menggunakan indikator HOTS yang sudah di sesuaikan ketercapaiannya dengan indikator soal. Subjek yang mencapai indikator pada level ini sudah mampu menggunakan informasi yang ada pada permasalahan kemudian memodelkan secara matematis dan membuat rencana penyelesaian untuk menjawab permasalahan yang diberikan.

\section{Simpulan dan Saran}

\section{Simpulan}

Berdasarkan data yang diperoleh setelah melakukan tes dan analisis untuk mengukur kemampuan literasi matematika dalam penyelesaian soal Higher Order Thinking Skills (HOTS) ditinjau pada Level 5 PISA terhadap Mahasiswa S1 Pendidikan Matematika diperoleh: Pada soal HOTS level 5 terdapat enam mahasiswa yang memiliki kemampuan matematika PISA yakni S2, S5, S9, S13, S11, S16 memenuhi keempat indikator. Kemampuan level 5 ini 


\section{ASIMTOT: JURNAL KEPENDIDIKAN MATEMATIKA}

Volume 2 Nomor 2, Juni - November 2020, halaman 91 - 101

Tersedia Daring pada https://journal.unwira.ac.id/index.php/ASIMTOT

diukur dengan menggunakan indikator HOTS yang sudah di sesuaikan ketercapaiannya dengan indikator soal. Subjek yang mencapai indikator pada level ini sudah mampu menggunakan informasi yang ada pada permasalahan kemudian memodelkan secara matematis dan membuat rencana penyelesaian untuk menjawab permasalahan yang diberikan.

\section{Saran}

Bagi peneliti berikutnya dapat diujicobakan soal yang lebih bervariasi lagi dan levelnya bisa di sesuaikan kembali. meliputi LOTS ataupun HOTS, dan dapat dari tingkatan yang paling dasar hingga yang paling tinggi seperti mahasiswa

\section{Daftar Pustaka}

Barczi, Krisztina. (2008). "A study on how Hungarian students solve problems that are unusual for them." Handbook of Mathematics Teaching Improvement: Professional Practices that address PISA.

Edo, S. I., Hartono, Y., Ilma, R. (2012). Investigating Secondary School Students'Difficulties in Modelling Problems PISA-Model level 5 and 6. Journal on Mathematics Education (IndoMS-JME), 3(2), 151-168.

Forster, M. (2004).Higher Order Thinking Skills.Research Development ,11, 2-6.

Kemdikbud.(2013). Materi Pelatihan Guru Implementasi Kurikulum 2013 SMP/MTs Matematika.Badan
Pengembangan Sumber Daya Manusia Pendidikan dan Kebudayaan dan Penjaminan Mutu Pendidikan Kementerian Pendidikan dan Kebudayaan. Jakarta: Kemdikbud.

Lutfianto, M. (2013) Unfinished Student Answer In Pisa Mathematics Contextual Problem. In: Zulkardi(Eds). The First South East Asia Design/ Development Research (SEA-DR) International Conference, April 22nd-23rd, 2013, Unsri, Palembang.

Mangelep, N. O. (2013). Pengembangan Soal Matematika pada Kompetensi Proses Koneksi dan Refleksi PISA.Jurnal Edukasi Matematika (Edumat), 4(7), 437-510.

OECD (2010). PISA 2012 Mathematics Framework: Draft Subject to Possible revision after the Field Trial.

OECD. (2013). PISA 2012 Assessment and Analytical Framework: Mathematics, Reading, Science, Problem Solving and Financial Literacy. Paris: OECD

Prasetyani, dan Suparman. 2018. Literasi Matematika dan Kemampuan Berpikir Tingkat Tinggi Mahasiswa kaitannya dengan Soal PISA. Prosiding Semnas UMP. 12 Mei 2018

Stacey, K. (2011) The View of Mathematics Literacy in Indonesia: Journal on Mathematics Education (IndoMS_JME). July 2011. Vol. 2: 1-24

Sugiyono. (2016). Memahami penelitian Kualitatif. Bandung: ALFABETA. 